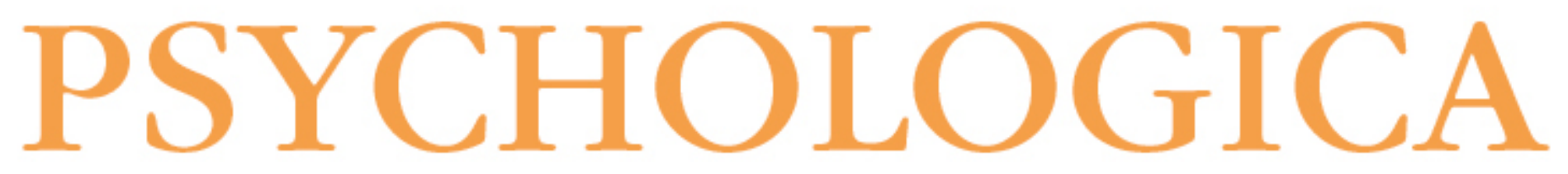

\title{
Issues of PTSD and blast-induced traumatic brain injury in armed conflicts and terrorists attacks
}

Autor(es): $\quad$ McCaffrey, Robert J.

Publicado por: Imprensa da Universidade de Coimbra

URL

persistente: URI:http://hdl.handle.net/10316.2/5420

DOI: $\quad$ DOI:http://dx.doi.org/10.14195/1647-8606_50_12

Accessed : $\quad$ 26-Apr-2023 13:51:25

A navegação consulta e descarregamento dos títulos inseridos nas Bibliotecas Digitais UC Digitalis, UC Pombalina e UC Impactum, pressupõem a aceitação plena e sem reservas dos Termos e Condições de Uso destas Bibliotecas Digitais, disponíveis em https://digitalis.uc.pt/pt-pt/termos.

Conforme exposto nos referidos Termos e Condições de Uso, o descarregamento de títulos de acesso restrito requer uma licença válida de autorização devendo o utilizador aceder ao(s) documento(s) a partir de um endereço de IP da instituição detentora da supramencionada licença.

Ao utilizador é apenas permitido o descarregamento para uso pessoal, pelo que o emprego do(s) título(s) descarregado(s) para outro fim, designadamente comercial, carece de autorização do respetivo autor ou editor da obra.

Na medida em que todas as obras da UC Digitalis se encontram protegidas pelo Código do Direito de Autor e Direitos Conexos e demais legislação aplicável, toda a cópia, parcial ou total, deste documento, nos casos em que é legalmente admitida, deverá conter ou fazer-se acompanhar por este aviso. 


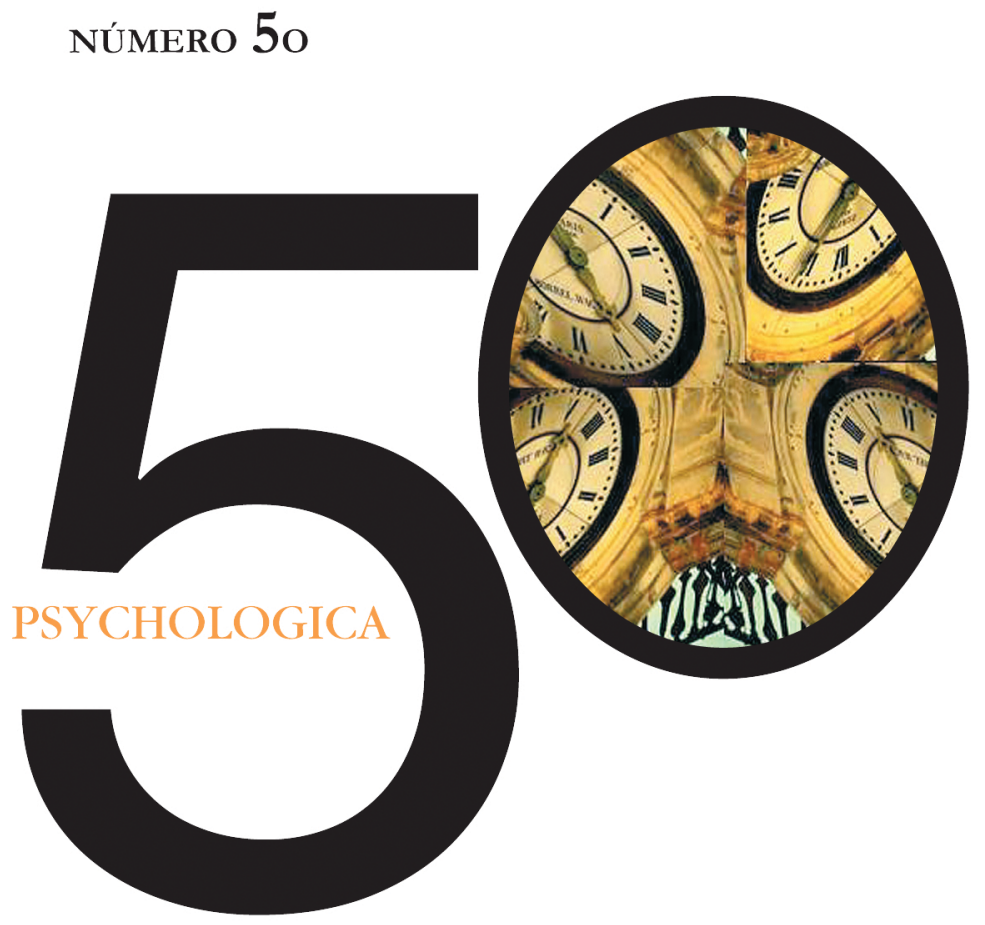

IMPRENSA DA UNIVERSIDADE DE COIMBRA

FACULDADE DE PSICOLOGIA E DE CIÊNCIAS DA EDUCAÇÃO DA UNIVERSIDADE DE COIMBRA 


\title{
Issues of PTSD and Blast-induced Traumatic Brain Injury in Armed Conflicts and Terrorists Attacks
}

\begin{abstract}
Robert J. McCaffrey'
Military conflicts and terrorisms attacks often result in both Posttraumatic Stress Disorder (PTSD) and blast-induced traumatic brain injuries. These conditions exist along a continuum of severity and this may have profound consequences particularly among those individuals who present with subthreshold PTSD or unrecognized blast-induced traumatic brain injury. The Diagnostic and Statistical Manual of Mental Disorders past approach has relied upon a categorical diagnostic system only. It is argued that a mixed categorical-dimensional classification system would be of greater benefit, especially since this system would include subthreshold conditions that do not meet DSM criteria for a diagnosis but that have demonstrable impacts upon an individuals' functioning.

This paper explores these issues in the hope of generating greater aware among practitioners' and the general public.
\end{abstract}

KEYWORDS: Traumatic Brain Injury; PTSD; Blast-induced Brain Injuries; Nosology; DSM.

The history of mankind is rife with armed conflicts and their psychological aftermaths. Recognition of a distinct psychological disorder associated with armed conflicts was not fully realized until after the Vietnam War with the addition of PTSD as a separate diagnosis in the Diagnostic and Statistical Manual of Mental Disorder - Third Edition (DMS-III, 1980). Prior to 1980, PTSD was variously referred to as battle-fatigue, shell-shock, etc. In addition to acknowledging traumatic events witnessed during armed conflict as the source of symptoms comprising the disorder of PTSD among military personnel, the DSM-III also extended this diagnosis to non-military forms of traumatic events encountered by civilian populations. The onset of PTSD could occur immediately following the traumatic event(s) or might have a delayed onset of unspecified time, as in the case of concentration camp survivors. The subtypes were Acute PSTD (i.e., symptom onset with six months of the trauma and symptoms of less than six months duration) Chronic PTSD or Delayed PTSD (i.e., duration of symptoms six months

1 State University of New York \& Albany Neuropsychological Associates 
or more (Chronic PTSD) and/or onset of symptoms six months or more after the traumatic event (Delayed PTSD). In order to diagnose PTSD under the DSM-III, the clinician first needed to determine if Criterion A had been met, specifically: "Existence of a recognizable stressor that would evoke significant symptoms of distress in almost everyone."(p. 238).

The revised version of the DMS-III, the Diagnostic and Statistical Manual of Mental Disorder-Third Edition-Revised (DSM-III-R, 1987) further defined the characteristics of PTSD by focusing on the definition of what constituted a Criterion A stressor. Specifically, under the DSM-III-R an individual could be diagnosed with PSTD if: "The person has experienced an event that is outside the range of usual human experience and that would be markedly distressing to almost anyone, e.g., serious threat to one's life or physical integrity; serious threat or harm to one's children, spouse, or other close relatives and friends; sudden destruction of one's home or community; or seeing another person who has recently been, or is being, seriously injured or killed as the result of an accident or physical violence" ( $p$. 250). In addition the symptoms comprising Criterion B, C, and D must have been present for at least one month.

In the Diagnostic and Statistical Manual of Mental Disorder - Fourth Edition (DSM-IV, 1994) Criteria A for a diagnosis of PTSD required that: "The person has been exposed to a traumatic event in which both the following were present: (1) the person experienced, witnessed, or was confronted with an event or events that involved actual or threatened death or serious injury, or a threat to the physical integrity of self or others (2) the person's response involved intense fear, helplessness, or horror" (p. 427 - 428). In addition, the DSM-IV noted a separate diagnostic category of Acute Stress Disorder in which the associated symptoms must be present for a minimum of two days and a maximum of 30 days, after which time if the associated symptoms persisted the diagnosis was changed to PTSD. Acute PTSD was defined as the symptoms being present for less than three months, while Chronic PTSD was defined as symptoms continuing beyond three months. Delayed onset was defined as symptom onset at least six months following the traumatic event. The diagnostic criteria for both Acute Stress Disorder and PTSD remained the same in the Diagnostic and Statistical Manual of Mental Disorder - Fourth Edition - Text Revision (DSM-IV-TR, 2000).

The Diagnostic and Statistical Manual of Mental Disorder - Fifth Edition committee is still meeting in secret closed door sessions. The American Psychiatric Association has utilized a categorical approach to defining the whether or not an individual meets the diagnostic criteria for a disorder, such as PTSD. Clinical psychologists have recently called for a paradigm shift from a "categorical only system" represented by all previous versions of the DSM, to a "mixed categorical-dimensional system" 
(Maser, Norman, Zisook, Everall, Stein, Schettler, \& Judd, 2009). The addition of a dimensional component acknowledges that there are subthreshold forms of psychopathology that do not fit neatly into a strictly categorical system but are nonetheless distressing to the individual. For example, data from community samples indicate that women exhibited a greater rate of subthreshold PTSD than full PTSD and those with subthreshold PTSD evidenced functional impairments in their educational and employment settings. Similar findings have been noted for depression and bipolar disorder (see Maser et al. (2009) for further review).

Armed conflicts, such as those in Iraq and Afghanistan, and acts of terrorism, such as the bombing of the subway station in Madrid in 2004 and in London in 2005 involving explosive devices have the potential to lead to both military and civilian casualties from blast injuries. While the course of PTSD in the aftermath of an explosive event are generally predictable, the role of blast-related-induced cognitive dysfunction is less clearly understood and may complicate the clinical presentation of an individual patient and impact on accurate diagnosis and treatment planning. The co-existence of PTSD and blast-related-induced cognitive dysfunction presents a unique diagnostic challenge and an opportunity for clinical neuropsychology to make major contributions in the care and treatment of the survivors.

\section{Blast-related traumatic brain injury}

Much of the early work involving traumatic brain injury among military forces focused on personnel who had sustained either penetrating missile wounds or open head injury. In contrast, the study of traumatic brain injury among the civilian population has focused largely on closed head injuries resulting from industrial accidents, sporting accidents and automobile accidents.

Blast-related brain trauma from improvised explosive devices and other explosive military munitions has been reported to occur in approximately $78 \%$ among military personnel in Iraq and Afghanistan (Owens, et al. 2008). These explosive devices can result in multiple injuries including traumatic brain injury, damages to internal organs, burns, fractures and amputations. There have been concerns expressed regarding the cognitive sequelae of blast-related traumatic brain injuries being fundamentally different based upon the mechanism of the brain trauma (i.e., a high-force blast wave or primary blast injury) as compared to that which occurs among civilians populations in motor vehicle accidents (i.e., an acceleration/ deceleration injury). The current clinical literature based upon non-military blast-related traumatic brain injury is sparse and has not directly compared groups of blast-induced brain injury to other mechanisms of brain injury. 
Recently, Belanger, Kretzmer, Yoash-Gantz, Pickett and Tupler (2009) compared the performance of military personnel who had sustained blast-related traumatic brain injury to the performance of military personnel who sustained non-blast or blunt force injury resulting in a traumatic brain injury. Both groups were subdivided into two subgroups consisting of either mild or moderate to severe traumatic brain injuries. The performance of the blast-related traumatic brain injury group was not statistically significantly different from the performance of the non-blast or blunt force traumatic brain injury group. While there was an interaction on the visual memory measure demonstrating better performance for the mild blast-related subgroup and poorer performance for the moderate to severe blast-related subgroup compared to both of the non-blast related subgroups, the neuropsychological findings did not indicate any convincing data that would suggest that blast-inducted traumatic brain injury is fundamentally different from non-blast related brain injury.

\section{The Neuropsychology of PTSD}

Many, if not all, psychiatric conditions have associated neuropsychological features. While these associated neuropsychological features may not rise to the level of a clinically significant complaint by the individual or be a primary focus of treatment, they may nonetheless have both theoretical and practical significance in the diagnosis and treatment of the individual's primary complaint. PTSD is one such example of a psychiatric disorder with associated neuropsychological features.

Research examining the associated neuropsychological findings among individuals suffering from PTSD has generally demonstrated the presence of less proficient performance on neuropsychological tasks relative to non-PTSD control groups. While the research in this area is not always consistent across studies, several of the associated neuropsychological findings of PTSD are also commonly found among individuals with various degrees of neurological insults, such as a traumatic brain injury. Specifically, neurological insults appear to be a potential risk factor for poorer psychological outcomes. The associated neuropsychological features of PTSD have been reported to involve less proficient performance in a number of cognitive domains including: immediate verbal memory, verbal fluency, verbal abstraction, visuomotor tracking and some aspects of attention and executive functioning (Vasterling \& Brailey, 2005). While these associated neuropsychological features have not been reported to rise to the level of global neuropsychological deficits, the presence of these subthreshold alterations in neuropsychological performance may interact, in as yet an unknown manner, among individuals with undiagnosed blast-related traumatic brain injury. 


\section{Diagnostic and Treatment Considerations}

Veterans of armed conflicts and civilians of terrorist attacks may develop PTSD or evidence a blast-related traumatic brain injury. This dichotomy is arbitrary and should never be presumed. The use of the Diagnostic and Statistical Manual of Mental Disorders relies on categorical dimensions in arriving at a specific diagnosis. As such, the criteria for a specific condition are either fully met or they are not. The application of a "mixed categorical-dimensional system" to the issue diagnosis, treatment planning and continuing care among veterans and civilians who have experienced blast-related events poses several challenges to both clinical psychology and clinical neuropsychology. Theoretically, an individual could have either PTSD, a blast-related traumatic brain injury or suffer from both as meeting the current diagnostic criteria for each condition, separately. For those individuals who meet the diagnostic criteria for only one of the two conditions, their treatment and intervention plans may be profoundly and negatively impacted. As an example, consider an individual who meets the categorical DSM-IV diagnosis of PTSD but who also has a blast-related traumatic brain injury. If this individual were to begin to experience difficulties in his/her educational or employment setting, the clinician's treatment focus would likely be on relating these difficulties to PTSD. Unaware of the underlying, subthreshold sequelae from a blast-related traumatic brain injury would seriously compromise the individual's reintegration into the educational or occupational system.

There are several possible variants arising from considering a mixed categorical-dimensional system: PTSD dominant; blast-induced TBI dominant; both PTSD and blast-induced TBI subthreshold; PTSD dominant with blast-induced TBI subthreshold; blast-induced TBI dominant with PTSD subthreshold. Of course with each of subthreshold dimensions the degree of either PTSD or blast-induced TBI would vary. The presence of subthreshold PTSD and subthreshold blast-induced traumatic brain injury are likely to pose an important and significant challenge to clinical psychologists and clinical neuropsychologists working with military personnel and survivors of terrorist attack. These populations need to be evaluated not from the strict DSM categorical system approach but from a mixed categoricaldimensional system, which permits consideration of subthreshold conditions, in order to best meet these groups' unique needs.

\section{References}

American Psychiatric Association (1980). Diagnostic and Statistical Manual of Mental Disorders ( $3^{\text {rd }}$ ed.). Washington, DC: Author.

American Psychiatric Association (1987). Diagnostic and Statistical Manual of Mental Disorders ( $3^{\text {rd }}$ ed., revised). Washington, DC: Author. 
American Psychiatric Association (1994). Diagnostic and Statistical Manual of Mental Disorders ( $4^{\text {th }}$ ed.). Washington, DC: Author.

American Psychiatric Association (2000). Diagnostic and Statistical Manual of Mental Disorders ( $4^{\text {th }}$ ed., text revision). Washington, DC: Author.

Belanger, H. G., Kretzmer, T., Yoansh-Gantz, R., Pickett, T., \& Tupler, L. A. (2009). Cognitive sequelae of blast-related versus other mechanisms of brain trauma. Journal of the International Neuropsychological Society, 15, 1-8.

Maser, J. D., Norman, S. B., Zisook, S., Everall, E. P., Stein, M. B., Schettler, P. J.,\&Judd,L.L.(2009). Psychiatric nosology is ready for a paradigm shift in DSM-V. Clinical Psychology: Science and Practice, 16, 24-40.

Owens, B. D., Kragh, J. F., Wenke, J. C., Macaitis, J., Wade, C. E., \& Holcomb, J. B. Combat wounds in Operation Iraqi Freedom and Operation Enduring Freedom. Journal of Trauma, 64, 295-299.

Vasterling, J. J., \& Brailey, K. (2005). Neuropsychological findings in adults with PTSD. In J. J. Vasterling \& C. R. Brewin (eds.) Neuropsychology of PTSD (pp. 178-207). New York, NY: Guilford. 